\title{
Faktor Risiko Cemaran Escherichia coli pada Daging Kambing dan Domba Kurban di Provinsi DKI Jakarta
}

\section{Risk Factors of Escherichia coli contamination in Kurban Goat and Lamb Meat in Province of DKI Jakarta}

\author{
Wahyu Septiani ${ }^{1}$, Herwin Pisestyani ${ }^{2}$, Renova Ida Siahaan ${ }^{3},{ }^{,}$Chaerul Basri ${ }^{2 *}$, \\ ${ }^{1}$ Fakultas Kedokteran Hewan, Institut Pertanian Bogor \\ ${ }^{2}$ Departemen Ilmu Penyakit Hewan dan Kesehatan Masyarakat Veteriner, Fakultas Kedokteran Hewan, \\ Institut Pertanian Bogor \\ ${ }^{3}$ Laboratorium Kesehatan Masyarakat Veteriner, Dinas Ketahanan Pangan, Kelautan dan Pertanian, \\ Provinsi DKI Jakarta \\ *Corresponding Author, Email: chaerul@apps.ipb.ac.id
}

Naskah diterima: 22 Februari 2020, direvisi: 22 Mei 2020, disetujui: 10 Agustus 2020

\begin{abstract}
Escherichia coli is one of the biological hazards affecting the safety of Kurban goat and lamb meat. This research aimed to measure the level of contamination and determine the risk factors of $E$. coli in Kurban goat and lamb meat in Province of DKI Jakarta. This research used data about the health of Kurban meats in Province of DKI Jakarta. The level of contamination E. coli was obtained from laboratory tests using MPN method, while the risk factors data were obtained from the assessment's results of Kurban place eligibility using checklist. Data was analysed using the chi-square test to determine the association and the odds ratio (OR) to measure strength of association. The results showed that $66.7 \%$ of Kurban places had produced goat and sheep meat containing E. coli with levels exceeding the Indonesian National Standard/SNI $\left(1 \times 10^{1} \mathrm{MPN} / \mathrm{g}\right)$. The risk factor of cleaning animal manures had a significant association to the level of contamination E. coli in meat from Kurban. Kurban organizers must improve hygiene and sanitation practices in processing meat to control the level of contamination E. coli. The DKI Jakarta provincial government needs to increase efforts to improve public awareness through communication, education and information related to good handling practices of meat for Kurban.
\end{abstract}

Key words: Escherichia coli; goat; kurban; lamb; meat

\begin{abstract}
Abstrak
Escherichia coli merupakan salah satu bahaya biologis yang mempengaruhi keamanan daging kambing dan domba Kurban. Penelitian ini ditujukan untuk mengukur tingkat kontaminasi dan menentukan faktor risiko yang mempengaruhi tingkat cemaran E. coli pada daging kambing dan domba kurban di Provinsi DKI Jakarta. Penelitian ini menggunakan data dari hasil pemeriksaan kesehatan hewan dan daging Kurban. Tingkat kontaminasi E.coli diperoleh dari hasil pemeriksaan laboratorium dengan metode MPN, sedangkan data faktor risiko diperoleh dari penilaian kelayakan tempat kurban menggunakan checklist yang dikembangkan oleh tim Fakultas Kedokteran Hewan IPB University. Data dianalisis menggunakan uji chi-square untuk menentukan asosiasi dan rasio odds (OR) untuk mengukur kekuatan asosiasi. Hasil penelitian ini menunjukkan bahwa $66,7 \%$ tempat penyelenggaraan kurban telah menghasilkan daging kambing dan domba yang mengandung E. coli dengan level melampaui batas Standar Nasional Indonesia/SNI $\left(1 \times 10^{1} \mathrm{MPN} / \mathrm{g}\right)$. Faktor risiko selalu membersihkan kotoran hewan memiliki hubungan yang signifikan dengan tingkat kontaminasi E. coli. Penyelenggara Kurban harus meningkatkan praktik higiene dan sanitasi dalam mengolah daging untuk mengendalikan tingkat kontaminasi
\end{abstract}


E.coli. Pemerintah Provinsi DKI Jakarta perlu meningkatkan upaya untuk memperbaiki kesadaran masyarakat melalui komunikasi, edukasi dan informasi terkait praktik-praktik penanganan daging yang baik untuk Kurban.

Kata kunci: daging; domba; Escherichia coli; kambing; kurban.

\section{Pendahuluan}

Hari raya kurban atau Idul Adha merupakan hari raya bagi umat Islam untuk mendekatkan diri kepada Allah SWT dengan melakukan pemotongan hewan kurban. Hewan kurban yang disembelih merupakan binatang ternak, yaitu unta, sapi, kambing, dan domba. Kambing dan domba merupakan binatang ternak yang banyak dijadikan sebagai hewan kurban karena harganya yang lebih murah dibandingkan dengan unta dan sapi.

Daging kurban harus aman, sehat, utuh, dan halal (ASUH). Daging berpotensi menjadi media pertumbuhan mikrob seperti bakteri, karena daging memiliki nutrisi yang tinggi. Salah satu bakteri yang memengaruhi keamanan daging kambing dan domba kurban adalah cemaran Escherichia coli. Escherichia coli merupakan flora normal pada usus manusia maupun hewan yang kemudian dikeluarkan melalui feses (Berthe et al., 2013). Salah satu strain patogenik dari $E$. coli adalah E. coli O157:H7 yang ditemukan di feses (Suardana et al., 2010). Cemaran E. coli yang bersifat patogenik dapat menimbulkan foodborne disease. Gejala umum infeksi E. coli diantaranya diare berdarah, muntah, nyeri abdomen, dan kram perut (Kusumaningsih, 2010). Pemotongan hewan kurban di Indonesia biasanya dilakukan di lapangan atau halaman masjid. Kontaminasi bakteri E. coli dapat terjadi selama proses pemotongan hewan dan penanganan daging, kebersihan yang kurang terjaga, jumlah panitia yang terlalu banyak, dan lalu lalang manusia pada tempat penyembelihan.

Cemaran E. coli pada daging kurban dapat menyebabkan penurunan kualitas daging dan gangguan kesehatan jika dikonsumsi tanpa pengolahan yang benar. Usaha untuk meningkatkan kualitas daging dilakukan melalui pengolahan atau penanganan yang lebih baik sehingga dapat mengurangi kerusakan atau kebusukan selama penyimpanan (Afiati, 2009). Pencegahan dan pengendalian kejadian cemaran E. coli dapat dilakukan dengan cara meminimalisasi faktorfaktor yang memengaruhi cemaran E. coli pada daging.

Penelitian ini bertujuan mengukur tingkat cemaran dan menentukan faktor risiko cemaran Escherichia coli pada daging kambing dan domba kurban di wilayah DKI Jakarta. Manfaat dari penelitian ini adalah memberikan informasi mengenai tingkat cemaran dan faktor risiko cemaran Escherichia coli yang dapat dijadikan dasar untuk meningkatkan keamanan daging kambing dan domba kurban di wilayah DKI Jakarta.

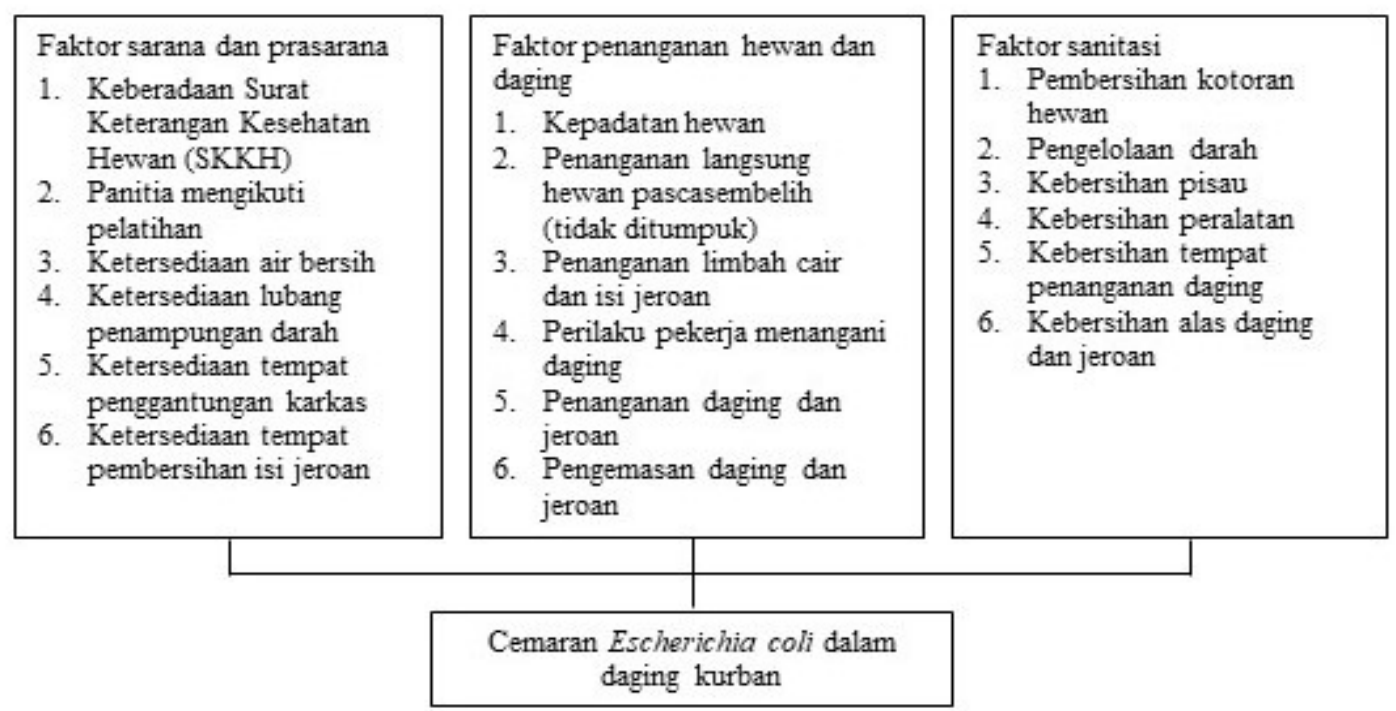

Gambar 1. Kerangka konsep penelitian 


\section{Materi dan Metode}

Penelitian ini merupakan studi epidemiologi dengan desain penelitian Cross Sectional di wilayah DKI Jakarta. Analisis data dilakukan di Laboratorium Epidemiologi, Divisi Kesehatan Masyarakat Veteriner dan Epidemiologi, Fakultas Kedokteran Hewan Institut Pertanian Bogor (FKH IPB). Kerangka konsep yang dibangun dalam penelitian ini digambarkan sebagai berikut pada Gambar 1.

Penelitian ini menggunakan data pemeriksaan hewan dan daging kurban tahun 2018 yang dilakukan Dinas Ketahanan Pangan, Kelautan dan Pertanian Provinsi DKI Jakarta. Data cemaran $E$. coli berasal dari hasil pemeriksaan kualitas mikrobiologik di Laboratorium Kesehatan Masyarakat Veteriner DKI Jakarta terhadap daging kurban. Data faktor risiko berasal dari hasil pemeriksaan kelayakan higiene dan sanitasi tempat pemotongan kurban menggunakan checklist terstruktur yang dirancang oleh tim FKH IPB. Pengurus masjid atau ketua pelaksana kurban merupakan responden dalam penelitian ini.

Pengujian sampel dilakukan dengan metode pengujian yang mengacu pada SNI 01-28972008 tentang Metode Pengujian Cemaran Mikroba dalam Daging, Telur dan Susu, serta Hasil Olahannya, yaitu pengujian Most Probable Number E. coli (BSN, 2008). Nilai MPN E. coli merupakan perkiraan atau estimasi jumlah $E$. coli dalam daging, dengan memupuk pada suatu tingkat pengenceran ke dalam tiga atau lima tabung berisi media cair. Nilai perhitungan MPN ditentukan menggunakan tabel MPN berdasarkan pengamatan jumlah tabung positif (timbulnya gas) (BSN, 2008).

Peubah yang diamati terdiri dari faktor sarana dan prasarana, faktor penanganan hewan dan daging kurban, serta faktor sanitasi. Peubah yang termasuk faktor sarana dan prasarana meliputi keberadaan Surat Keterangan Kesehatan Hewan (SKKH), panitia mengikuti pelatihan, ketersediaan air bersih, ketersediaan lubang penampungan darah, ketersediaan tempat penggantungan karkas, dan tempat pembersihan isi jeroan. Peubah yang termasuk faktor penanganan hewan dan daging kurban meliputi kepadatan hewan, penanganan langsung hewan pascasembelih (tidak ditumpuk), penanganan limbah cair dan isi jeroan, perilaku pekerja menangani daging, penanganan daging dan jeroan, serta pengemasan daging dan jeroan. Peubah faktor sanitasi meliputi pembersihan kotoran hewan, pengelolaan darah, kebersihan pisau, kebersihan peralatan, kebersihan tempat penanganan daging, serta kebersihan alas daging dan jeroan.

Data dianalisis secara analitik menggunakan uji chi-square untuk menentukan hubungan dan odds ratio (OR) untuk mengukur kekuatan hubungan antara faktor risiko terhadap keberadaan E. coli dalam daging kambing dan domba kurban di tempat pemotongan hewan kurban wilayah DKI Jakarta. Hasil signifikan ditunjukkan apabila nilai p pada taraf uji 5\% (P value < 0.05). Data dianalisis dengan menggunakan piranti lunak Microsoft Excel 2017 dan SPSS v.21.

\section{Hasil dan Pembahasan}

\section{Tingkat Cemaran Escherichia coli}

Persentase jumlah E. coli pada daging kambing dan domba kurban tersedia pada Tabel 1. Sebagian besar sampel daging kambing dan domba yang diperiksa menunjukkan jumlah $E$. coli di atas ambang batas SNI. Kontaminasi yang telah ditetapkan dalam SNI 01-7388-2009 tentang Batas Maksimum Cemaran Mikroba dalam Pangan, batas maksimum jumlah E. coli dalam daging adalah $1 \times 10^{1} \mathrm{MPN} / \mathrm{g}$ (BSN, 2009).

Tabel 1. Persentase jumlah E. coli pada daging kambing dan domba kurban pada tahun 2018

\begin{tabular}{lcrr}
\hline Wilayah & Jumlah sampel & \multicolumn{2}{c}{ Tingkat cemaran E. coli } \\
\hline Jakarta Pusat & & Di bawah SNI $(\%)$ & Di atas SNI (\%) \\
Jakarta Utara & 5 & $10.00(3 / 30)$ & $13.33(4 / 30)$ \\
Jakarta Barat & 4 & $3.33(1 / 30)$ & $13.33(4 / 30)$ \\
Jakarta Selatan & 9 & $10.00(3 / 30)$ & $3.33(1 / 30)$ \\
Jakarta Timur & 5 & $6.67(2 / 30)$ & $23.33(7 / 30)$ \\
Total & 30 & $3.33(1 / 30)$ & $13.33(4 / 30)$ \\
\hline
\end{tabular}


Berdasarkan Tabel 1, jumlah E. coli di bawah ambang batas SNI sebesar 33.33\% (10/30), sedangkan di atas ambang batas SNI sebesar $66.67 \%$ (20/30). Hal ini menunjukkan cemaran E. coli pada daging kambing dan domba kurban wilayah DKI Jakarta masih berada di atas batas maksimum SNI, sehingga perlu perhatian lebih lanjut terhadap faktor-faktor yang memengaruhi cemaran E. coli. Menurut Purwanti (2006), tingginya persentase cemaran $E$. coli pada daging kambing sebesar $41.3 \%$ dapat disebabkan oleh adanya proses cemaran melalui air. Escherichia coli merupakan salah satu bakteri dari golongan Koliform yang menjadi indikator pencemaran feses pada air (Afrisetiawati et al., 2016). Cemaran E. coli terhadap lingkungan dapat terjadi melalui kotoran ternak, limbah pemotongan hewan, dan air limbah (Jang et al., 2017).

\section{Faktor Risiko terkait Sarana dan Prasarana}

Faktor sarana dan prasarana meliputi keberadaan Surat Keterangan Kesehatan Hewan (SKKH), panitia mengikuti pelatihan, ketersediaan air bersih, ketersediaan lubang penampungan darah, ketersediaan tempat penggantungan karkas, dan tempat pembersihan isi jeroan. Hubungan antara faktor sarana dan prasarana terhadap keberadaan E. coli dalam daging kambing dan domba kurban tersedia pada Tabel 2. Hasil penelitian menunjukkan persentase faktor-faktor sarana dan prasarana, yaitu keberadaan SKKH sebesar $73.33 \%$ (22/30), panitia mengikuti pelatihan penyembelihan hewan kurban dan penanganan daging yang higienis sebesar $73.33 \%$ (22/30), ketersediaan air bersih yang memadai sebesar 93.33\% (28/30), ketersediaan lubang khusus penampungan darah sebesar 66.67\% (20/30), ketersediaan tempat penggantungan karkas sebesar $83.33 \%$ (25/30), dan ketersediaan tempat pembersihan isi jeroan sebesar 66.67\% (20/30).

Berdasarkan uji chi-square, semua peubah terkait faktor sarana dan prasarana yang terdiri atas keberadaan SKKH, panitia mengikuti pelatihan, ketersediaan air bersih, ketersediaan lubang penampungan darah, ketersediaan tempat penggantungan karkas, dan ketersediaan tempat pembersihan isi jeroan tidak menunjukkan hasil yang signifikan $(\mathrm{P}$ value $>0.05)$ yang berarti bahwa semua peubah tersebut tidak berhubungan terjadinya cemaran E. coli pada daging kurban.

Adanya SKKH pada domba atau kambing hidup yang dipotong pada kurban ternyata tidak memiliki perngaruh terhadap tingkat kontaminasi E. coli pada daging yang dihasilkan. Menurut Kementan (2014), SKKH merupakan bukti tertulis yang menjamin status kesehatan ternak dari daerah

Tabel 2. Hubungan antara faktor sarana dan prasarana terhadap keberadaan E. coli dalam daging kambing dan domba kurban

\begin{tabular}{|c|c|c|c|c|c|c|c|c|c|}
\hline \multirow{3}{*}{ No } & \multirow{3}{*}{ Peubah } & \multirow[t]{3}{*}{ Kategori } & \multicolumn{4}{|c|}{ Tingkat cemaran E. coli } & \multirow{3}{*}{ Nilai p } & \multirow{3}{*}{ OR } & \multirow{3}{*}{ SK 95\% } \\
\hline & & & \multicolumn{2}{|c|}{ Di bawah SNI } & \multicolumn{2}{|c|}{ Di atas SNI } & & & \\
\hline & & & $\mathrm{n}$ & $\%$ & $\mathrm{n}$ & $\%$ & & & \\
\hline \multirow[t]{2}{*}{1} & \multirow[t]{2}{*}{ Keberadaan SKKH } & $\mathrm{Ya}$ & 5 & 62.50 & 3 & 37.50 & \multirow[t]{2}{*}{0.08} & \multirow[t]{2}{*}{5.67} & \multirow[t]{2}{*}{$0.99-32.43$} \\
\hline & & Tidak & 5 & 22.73 & 17 & 77.27 & & & \\
\hline \multirow[t]{2}{*}{2} & \multirow[t]{2}{*}{ Panitia mengikuti pelatihan } & Ya & 3 & 37.50 & 5 & 62.50 & \multirow[t]{2}{*}{1.00} & \multirow[t]{2}{*}{1.29} & \multirow[t]{2}{*}{$0.24-6.96$} \\
\hline & & Tidak & 7 & 31.80 & 15 & 68.20 & & & \\
\hline \multirow[t]{2}{*}{3} & \multirow[t]{2}{*}{ Ketersediaan air bersih } & $\mathrm{Ya}$ & 1 & 50 & 1 & 50 & \multirow[t]{2}{*}{1.00} & \multirow[t]{2}{*}{2.11} & \multirow[t]{2}{*}{$0.12-37.72$} \\
\hline & & Tidak & 9 & 32.14 & 19 & 67.86 & & & \\
\hline \multirow[t]{2}{*}{4} & \multirow{2}{*}{$\begin{array}{l}\text { Ketersediaan lubang } \\
\text { penampungan darah }\end{array}$} & Ya & 4 & 40 & 6 & 60 & \multirow[t]{2}{*}{0.69} & \multirow[t]{2}{*}{1.56} & \multirow[t]{2}{*}{$0.32-7.59$} \\
\hline & & Tidak & 6 & 30 & 14 & 70 & & & \\
\hline \multirow[t]{2}{*}{5} & \multirow{2}{*}{$\begin{array}{l}\text { Ketersediaan tempat } \\
\text { penggantungan karkas }\end{array}$} & $\mathrm{Ya}$ & 2 & 40 & 3 & 60 & \multirow[t]{2}{*}{1.00} & \multirow[t]{2}{*}{1.42} & \multirow[t]{2}{*}{$0.19-10.23$} \\
\hline & & Tidak & 8 & 32 & 17 & 68 & & & \\
\hline \multirow[t]{2}{*}{6} & \multirow{2}{*}{$\begin{array}{l}\text { Ketersediaan tempat } \\
\text { pembersihan isi jeroan }\end{array}$} & $\mathrm{Ya}$ & 4 & 40 & 6 & 60 & 0.69 & 1.56 & $0.32-7.59$ \\
\hline & & Tidak & 6 & 30 & 14 & 70 & & & \\
\hline & ggan: & & & & & & & & \\
\hline $\begin{array}{l}\mathrm{n} \\
\text { Nilai p } \\
*\end{array}$ & $\begin{array}{l}: \text { ukuran sampel } \\
: \text { batas kemaknaan } \\
: \text { signifikan pada taraf uji 5\% }\end{array}$ & $l=0,05)$ & $\begin{array}{l}\text { OR } \\
\text { SK } 95 \%\end{array}$ & $\begin{array}{l}: \text { odds rc } \\
: \text { selang }\end{array}$ & & & & & \\
\hline
\end{tabular}


asal yang telah diperiksa oleh dokter hewan berwenang. Keberadaan SKKH menunjukkan bahwa ternak berasal dari peternakan yang sehat dan telah diperiksa oleh dokter hewan berwenang (Basri et al., 2013). Berdasarkan hal tersebut kemungkinan tingkat kontaminasi E. coli pada daging kurban lebih banyak dipengaruhi oleh penanganan hewan setelah disembelih dan penanganan daging setelah dipotong-potong dibandingkan dengan kondisi hewan saat masih hidup.

Hasil penelitian ini menunjukkan bahwa pengerjaan karkas hewan kurban dengan digantung ternyata tidak mempengaruhi tingkat kontaminasi E. coli pada daging yang dihasilkan. Hasil ini tidak sesuai dengan pernyataan Azwarini (2013) bahwa pengerjaan karkas dengan cara digantung dapat menurunkan kontaminasi terhadap E. coli. Dampak E. coli di lingkungan akan menyebabkan daging terkontaminasi $E$. coli, karena secara tidak langsung lingkungan terkontaminasi feses yang kemudian akan mencemari daging hewan kurban (Jian, 2016).

\section{Faktor Risiko terkait Penanganan Hewan dan Daging}

Faktor penanganan hewan dan daging meliputi kepadatan hewan, penanganan langsung he- wan pascasembelih (tidak ditumpuk), penanganan limbah cair dan isi jeroan, perilaku pekerja menangani daging, penanganan daging dan jeroan, serta pengemasan daging dan jeroan. Penanganan daging seharusnya dilakukan di meja khusus, penanganan jeroan dilakukan terpisah dengan tempat pemotongan daging, serta daging dan jeroan dalam kemasan terpisah (Azwarini, 2013). Hubungan antara faktor-faktor penanganan hewan dan daging kurban terhadap keberadaan E. coli dalam daging kambing dan domba kurban tersedia pada Tabel 3.

Berdasarkan uji chi-square diperoleh hasil bahwa semua peubah faktor yang berkaitan dengan penanganan hewan dan daging kurban yang terdiri atas kepadatan hewan, penanganan langsung hewan pascasembelih, penanganan limbah cair dan isi jeroan, perilaku pekerja menangani daging, penanganan daging dan jeroan, dan pengemasan daging dan jeroan tidak menunjukkan hasil yang signifikan ( $\mathrm{P}$ value $>0.05)$.

Hasil analisis menunjukkan bahwa kepadatan hewan sebelum dipotong tidak mempengaruhi terhadap tingkat kontaminasi $E$. coli pada daging yang dihasilkan. Menurut Kementan (2014), untuk menjaga kesehatan hewan maka tempat penampungan hewan harus memiliki luas yang sesuai dengan jumlah dan jenis hewan kurban

Tabel 3. Hubungan antara faktor penanganan hewan dan daging kurban terhadap keberadaan E. coli dalam daging kambing dan domba kurban

\begin{tabular}{|c|c|c|c|c|c|c|c|c|c|}
\hline \multirow{3}{*}{ No } & \multirow{3}{*}{ Peubah } & \multirow{3}{*}{ Kategori } & \multicolumn{4}{|c|}{ Tingkat cemaran E. coli } & \multirow{3}{*}{ Nilai p } & \multirow{3}{*}{ OR } & \multirow{3}{*}{ SK $95 \%$} \\
\hline & & & \multicolumn{2}{|c|}{ Di bawah SNI } & \multicolumn{2}{|c|}{ Di atas SNI } & & & \\
\hline & & & $\mathrm{n}$ & $\%$ & $\mathrm{n}$ & $\%$ & & & \\
\hline \multirow[t]{2}{*}{1} & \multirow[t]{2}{*}{ Kepadatan hewan } & Ya & 3 & 75.00 & 1 & 25.00 & \multirow[t]{2}{*}{0.09} & \multirow[t]{2}{*}{8.14} & \multirow[t]{2}{*}{$0.72-91.89$} \\
\hline & & Tidak & 7 & 26.90 & 19 & 73.10 & & & \\
\hline \multirow[t]{2}{*}{2} & \multirow{2}{*}{$\begin{array}{l}\text { Penanganan langsung hewan } \\
\text { pascasembelih (tidak ditumpuk) }\end{array}$} & Ya & 5 & 55.56 & 4 & 44.44 & \multirow[t]{2}{*}{0.12} & \multirow[t]{2}{*}{4.00} & \multirow[t]{2}{*}{$0.77-20.92$} \\
\hline & & Tidak & 5 & 23.81 & 16 & 76.19 & & & \\
\hline \multirow[t]{2}{*}{3} & \multirow{2}{*}{$\begin{array}{l}\text { Penanganan limbah cair dan isi jeroan } \\
\text { dengan baik }\end{array}$} & $\mathrm{Ya}$ & 4 & 33.33 & 8 & 66.67 & \multirow[t]{2}{*}{1.00} & \multirow[t]{2}{*}{1.00} & \multirow[t]{2}{*}{$0.21-4.71$} \\
\hline & & Tidak & 6 & 33.33 & 12 & 66.67 & & & \\
\hline \multirow[t]{2}{*}{4} & \multirow[t]{2}{*}{ Perilaku bersih pekerja menangani daging } & $\mathrm{Ya}$ & 4 & 36.36 & 7 & 63.64 & \multirow[t]{2}{*}{1.00} & \multirow[t]{2}{*}{1.24} & \multirow[t]{2}{*}{$0.26-5.91$} \\
\hline & & Tidak & 6 & 31.58 & 13 & 68.42 & & & \\
\hline \multirow[t]{2}{*}{5} & \multirow[t]{2}{*}{ Penanganan daging dan jeroan terpisah } & $\mathrm{Ya}$ & 2 & 28.57 & 5 & 71.43 & \multirow[t]{2}{*}{1.00} & \multirow[t]{2}{*}{0.75} & \multirow[t]{2}{*}{$0.12-4.77$} \\
\hline & & Tidak & 8 & 34.78 & 15 & 65.22 & & & \\
\hline \multirow[t]{2}{*}{6} & \multirow[t]{2}{*}{ Pengemasan daging dan jeroan terpisah } & Ya & 4 & 50 & 4 & 50 & \multirow[t]{2}{*}{0.38} & 2.67 & $0.50-14.22$ \\
\hline & & Tidak & 6 & 27.27 & 16 & 72.73 & & & \\
\hline
\end{tabular}

Keterangan:

n : ukuran sampel

Nilai $\mathrm{p}$ : batas kemaknaan

signifikan pada taraf uji 5\% $(\alpha=0,05)$
OR : odds ratio

SK 95\% : selang kepercayaan 95\% 
yang ditampung. Menurut Direktorat Kesehatan Masyarakat Veteriner (2019), kepadatan tempat penampungan hewan kurban untuk kambing dan domba dipersyaratkan memiliki luas minimal 1 $\mathrm{m}^{2} /$ ekor.

Analisis yang dilakukan menunjukkan tidak ada hubungan antara penanganan langsung hewan pascasembelih dengan cara ditumpuk dengan tingkat kontaminasi $E$. coli pada daging yang dihasilkan. Hewan yang telah disembelih harus dipastikan mati terlebih dahulu sebelum proses pengulitan. Hewan yang telah disembelih harus dibiarkan mati sempurna, kemudian dilakukan pemisahan kepala dan teracak, penggantungan, dan pengulitan (Pisestyani et al., 2015). Tingkat kontaminasi E. coli pada daging kurban kemungkinan tidak banyak dipengaruhi oleh penanganan hewan sesaat setelah dipotong, akan tetapi lebih banyak dipengaruhi oleh penanganan saat pengeluaran jeroan.

\section{Faktor Risiko terkait Sanitasi}

Sanitasi menurut World Health Organization (WHO) adalah suatu usaha yang mengawasi beberapa faktor lingkungan fisik yang berpengaruh kepada manusia terutama terhadap hal-hal yang memengaruhi efek, merusak perkembangan fisik, kesehatan, dan kelangsungan hidup. Sanitasi bertujuan untuk membunuh semua mikrob yang terdapat pada peralatan dan wadah yang digunakan. Oleh karena itu, peralatan pengolahan pangan sebaiknya dipilih yang mudah dibersihkan, mudah digunakan serta terbuat dari bahan yang anti karat (Azwarini, 2013). Faktor sanitasi juga sangat memengaruhi keamanan daging. Bakteri indikator sanitasi yang biasa dikenal yaitu $E$. coli. Keberadaan E. coli dalam pangan menunjukkan bahwa pangan tersebut pernah tercemar oleh kotoran yang berasal dari usus manusia dan atau hewan (Saimah et al., 2016).

Faktor sanitasi meliputi pembersihan kotoran hewan, pengelolaan darah, kebersihan pisau, kebersihan peralatan, kebersihan tempat penanganan daging, serta kebersihan alas daging dan jeroan. Hubungan antara faktor sanitasi terhadap keberadaan E. coli dalam daging kambing dan domba kurban tersedia pada Tabel 4.

Hasil penelitian menunjukkan persentase faktor-faktor sanitasi, yaitu kotoran hewan yang dibersihkan sebesar 76.67\% (23/30), pengelolaan darah tidak dibiarkan berceceran di atas tanah atau lantai sebesar 63.33\% (19/30), kebersihan pisau sebesar $80.00 \%(24 / 30)$, kebersihan peralatan sebesar $73.33 \% \quad(22 / 30)$, kebersihan tempat penanganan daging sebesar $66.67 \%$ (20/30), serta daging dan jeroan yang telah dipotong-potong

Tabel 4. Hubungan antara faktor sanitasi terhadap keberadaan E. coli dalam daging kambing dan domba kurban

\begin{tabular}{|c|c|c|c|c|c|c|c|c|c|}
\hline \multirow{3}{*}{ No } & \multirow{3}{*}{ Peubah } & \multirow{3}{*}{ Kategori } & \multicolumn{4}{|c|}{ Tingkat cemaran $E$. coli } & \multirow{3}{*}{ Nilai p } & \multirow{3}{*}{ OR } & \multirow{3}{*}{ SK $95 \%$} \\
\hline & & & \multicolumn{2}{|c|}{ Di bawah SNI } & \multicolumn{2}{|c|}{ Di atas SNI } & & & \\
\hline & & & $\mathrm{n}$ & $\%$ & $\mathrm{n}$ & $\%$ & & & \\
\hline \multirow[t]{2}{*}{1} & Pembersihan kotoran hewan & Ya & 5 & 71.43 & 2 & 28.57 & $0.03 *$ & 9.00 & $1.33-61.14$ \\
\hline & & Tidak & 5 & 21.74 & 18 & 78.26 & & & \\
\hline \multirow[t]{2}{*}{2} & Pengelolaan darah & $\mathrm{Ya}$ & 2 & 18.18 & 9 & 81.82 & 0.25 & 0.31 & $0.05-1.82$ \\
\hline & & Tidak & 8 & 42.11 & 11 & 57.89 & & & \\
\hline \multirow[t]{2}{*}{3} & Kebersihan pisau & $\mathrm{Ya}$ & 2 & 33.33 & 4 & 66.67 & 1.00 & 1.00 & $0.15-6.67$ \\
\hline & & Tidak & 8 & 33.33 & 16 & 66.67 & & & \\
\hline \multirow[t]{2}{*}{4} & Kebersihan peralatan & Ya & 3 & 37.50 & 5 & 62.50 & 1.00 & 1.29 & $0.24-6.96$ \\
\hline & & Tidak & 7 & 31.82 & 15 & 68.18 & & & \\
\hline \multirow[t]{2}{*}{5} & Kebersihan tempat penanganan daging & Ya & 3 & 30 & 7 & 70 & 1.00 & 0.79 & $0.16-4.08$ \\
\hline & & Tidak & 7 & 35 & 13 & 65 & & & \\
\hline \multirow[t]{2}{*}{6} & Kebersihan alas daging dan jeroan & $\mathrm{Ya}$ & 3 & 37.50 & 5 & 62.50 & 1.00 & 1.29 & $0.24-6.96$ \\
\hline & & Tidak & 7 & 31.82 & 15 & 68.18 & & & \\
\hline
\end{tabular}

Keterangan:

n : ukuran sampel

Nilai p : batas kemaknaan

* $\quad$ : signifikan pada taraf uji $5 \%(\alpha=0,05)$

OR : odds ratio

SK 95\% : selang kepercayaan 95\% 
disimpan pada alas yang bersih sebesar $73.33 \%$ (22/30). Berdasarkan uji chi-square menunjukkan hubungan signifikan antara peubah pembersihan kotoran hewan dengan keberadaan E. coli (P value $=0.03)$. Nilai OR yang diperoleh adalah $9.00(\mathrm{SK}$ $95 \% ; 1.33-61.14)$. Hal ini menunjukkan bahwa risiko cemaran $E$. coli pada daging terjadi 9 kali lebih besar jika kotoran hewan tidak dibersihkan dibandingkan dengan kotoran hewan yang dibersihkan di tempat pemotongan.

Sumber E. coli antara lain kotoran hewan atau lingkungan sekitar kandang (Suwito et al., 2018). Oleh sebab itu, kotoran hewan yang dibersihkan di tempat pemotongan dapat menurunkan cemaran E. coli pada daging kambing dan domba kurban. Kotoran hewan yang tidak dibersihkan di tempat pemotongan dapat terbawa oleh pekerja atau peralatan, sehingga menyebabkan kontaminasi silang ketika pekerja atau peralatan bersentuhan dengan daging. Risiko daging terkontaminasi lebih besar terjadi ketika permukaan daging bersentuhan dengan tangan yang tidak menggunakan sarung tangan (Jian, 2016).

Kontaminasi pada daging biasanya terjadi selama pemotongan dan pemrosesan daging melalui kontak dengan kulit yang terkontaminasi dengan kotoran (Erickson dan Doyle, 2007). Menurut Rananda (2016), beberapa faktor yang menjadi sumber kontaminasi bakteri $E$. coli, yaitu kontaminasi silang antara tangan pemotong yang terkontaminasi dengan daging, alat pemotong daging dan lantai tempat pemotongan menjadi sarana bakteri $E$. coli berpindah tempat ke daging. Cara terbaik untuk mencegah kontaminasi E. coli adalah dengan selalu mencuci tangan dengan air mengalir dan sabun segera setelah kontak dengan hewan, lingkungan hewan atau kotoran hewan (Daly et al., 2017). Cara untuk menurunkan atau membunuh bakteri E. coli dalam daging salah satunya dengan memasak daging hingga matang sempurna dengan suhu minimal $70^{\circ} \mathrm{C}$ (suhu aman untuk membunuh mikroba) selama 10 menit. Daging kambing disimpan tidak lebih dari 6 jam pada suhu ruang agar daging tetap berkualitas baik (Sembiring et al., 2015).

\section{Kesimpulan}

Kesimpulan dari penelitian ini adalah $66,7 \%$ tempat penyelenggaraan kurban telah menghasilkan daging kambing dan domba yang mengandung E. coli yang melampaui batas Standar Nasional Indonesia /SNI $\left(1 \times 10^{1}\right.$ MPN/g). Tingginya cemaran E. coli disebabkan oleh faktor pembersihan kotoran hewan di tempat pemotongan. Tempat pemotongan yang tidak membersihkan kotoran saat pemotongan berisiko 9 kali lebih besar untuk tercemar E. coli dibandingkan dengan yang selalu membersihkan kotoran. Hal ini menunjukkan pentingnya untuk selalu membersihkan kotoran hewan yang dihasilkan dari proses pemotongan hewan di tempat kurban karena dapat menjadi sumber kontaminasi mikroba terutama E.coli pada daging kurban.

\section{Ucapan Terima Kasih}

Kami menyampaikan terima kasih kepada panitia hewan kurban FKH IPB dan Dinas Ketahanan Pangan, Kelautan, dan Pertanian Provinsi DKI Jakarta yang telah membantu dalam pelaksanaan penelitian ini.

\section{Daftar Pustaka}

Afiati, F. (2009). Pilih-pilih daging ASUH. BioTrends. 4(1): 19-25.

Afrisetiawati R., Erly, dan Endrinaldi.( 2016). Identifikasi bakteri Escherichia coli pada air minum isi ulang yang diproduksi DAMIU di Kelurahan Lubuk Buaya Kota Padang. Jurnal Kesehatan Andalas. 5(3):570-574.

Azwarini, R. (2013). Kondisi Sanitasi Peralatan dan Tempat Pemotongan Serta Tingkat Kontaminasi Mikrob dalam Daging Kurban Di DKI Jakarta. Skripsi. Fakultas Kedokteran Hewan Institut Pertanian Bogor, Bogor.

Basri C., Zudanang, Sunandar, dan Sudarnika E. (2013). Faktor risiko terkait manajemen kesehatan unggas terhadap infeksi virus Flu Burung di tempat penampungan ayam. Jurnal Veteriner. 14 (2):197-203.

Berthe T., Ratajczak M., Clermont O., Denamur E., and Petit F. (2013). Evidence for coexistence of distinct Escherichia coli populations in various aquatic environments and their survival in estuary water. Applied 
and Environmental Microbiology. 79: 46844693.

[BSN] Badan Standardisasi Nasional. (2008). SNI 2897:2008 tentang Metode Pengujian Cemaran Mikroba dalam Daging, Telur dan Susu, serta Hasil Olahannya. Jakarta (ID): Badan Standardisasi Nasional.

[BSN] Badan Standardisasi Nasional. (2009). SNI 7388:2009 tentang Batas Maksimum Cemaran Mikroba dalam Pangan. Jakarta (ID): Badan Standardisasi Nasional.

Daly R.F., House J., Stanek D., and Stobierski M.G. (2017). Compendium of measures to prevent disease associated with animals in public settings. Journal of the American Veterinary Medical Association. 251(11):1268-1292.

Direktorat Kesehatan Masyarakat Veteriner. (2019). Pedoman Penerapan Kesejahteraan Hewan pada Pemotongan Hewan Kurban. Jakarta (ID): Direktorat Kesehatan Masyarakat Veteriner.

Erickson M.C., and Doyle M.P. (2007). Food as a vehicle for transmission of Shiga toxinproducing Escherichia coli. Journal of Food Protection. 70:2426-2449.

Jang J., Hur H.G., Sadowsky M.J., and Byappanahalli M.N., Yan T., Ishii S. (2017). Environmental Escherichia coli: ecology and public health implication-a review. Applied and Environmental Microbiology. 123:570-581.

Jian J.O.Z. (2016). Isolasi dan Identifikasi Bakteri Escherichia coli Patogen pada Daging, Feses Dan Hati Sapi. Skripsi. Fakultas Kedokteran Hewan Institut Pertanian Bogor, Bogor.

[Kementan] Kementerian Pertanian Republik Indonesia. (2014). Peraturan Menteri Pertanian Republik Indonesia Nomor 114 Tahun 2014 tentang Pemotongan Hewan Kurban. Jakarta (ID): Kementan RI.
Kusumaningsih A. (2010). Beberapa bakteri patogenik penyebab foodborne disease pada bahan pangan asal ternak. Wartazoa. 20(3): 103-111.

Pisestyani H., Dannar N.N., Santoso K., dan Latif H. (2015). Kesempurnaan kematian sapi setelah penyembelihan dengan dan tanpa pemingsanan berdasarkan parameter waktu henti darah memancar. Acta Veterinaria Indonesiana. 3(2):58-63.

Purwanti U. (2006). Hubungan antara sanitasi tempat pemotongan hewan qurban dengan cemaran mikrob pada daging kambing di Kotamadya Jakarta Timur Tesis. Bogor (ID): Institut Pertanian Bogor.

Rananda R.M., Djamal A., dan Julizar. (2016). Identifikasi bakteri Escherichia coli $\mathrm{O} 157: \mathrm{H} 7$ dalam daging sapi yang berasal dari Rumah Potong Hewan Lubuk Buaya. Jurnal Kesehatan Andalas. 5(3):614-618.

Saimah, Sudarwanto M.B., dan Latif H. (2016). Dekontaminasi bakteri Escherichia coli dan Staphylococcus aureus pada sarang burung walet dengan perlakuan pemanasan. Jurnal Kedokteran Hewan. 10(2):143-147.

Sembiring U.R., Suada I.K., dan Agustina K.K. (2015). Kualitas daging kambing yang disimpan pada suhu ruang ditinjau dari uji subjektif dan objektif. Indonesia Medicus Veterinus. 4(2):155-162.

Suardana I.W., Artama W.T., Asmara W., dan Daryono B.S. (2010). Identifikasi Escherichia coli 0157:H7 serta deteksi gen shiga like toxin 1 dan 2 asal feses hewan, daging, dan feses manusia. Jurnal Veteriner. 11(4):264-270.

Suwito W., Winarti E., Kristiyanti F., Widyastuti A., dan Andriani A. (2018). Faktor risiko terhadap total bakteri, Staphylococcus aureus, Coliform dan Escherichia coli pada susu kambing. Agricultural Technology. 38(1):39-44. 